\title{
Ecosystem approaches to human health
}

\author{
Abordagens ecossistêmicas à saúde humana
}

N. Ole Nielsen 1

\footnotetext{
1 Department of Pathobiology, University of Guelph. 11- 51127 Range Road 255, Spruce Grove, Alberta T7Y 1A8, Canada olen@telusplanet.net
}

\begin{abstract}
The promotion of human health must be embedded in the wider pursuit of ecosystem health. Interventions will be impaired if ecosystem-linked determinants of health are not taken into account. In the extreme case, if ecosystems lose their capacity for renewal, society will lose life support services. Essential features of ecosystem health are the capacity to maintain integrity and to achieve reasonable and sustainable human goals. An ecosystem approach to research and management must be transdisciplinary and assure participation of stakeholders. These requisites provide a means for science to better deal with the complexity of ecosystems, and for policy-makers and managers to establish and achieve reasonable societal goals. The ecosystem approach can determine links between human health and activities or events which disturb ecosystem state and function. Examples are: landscape disturbance in agriculture, mining, forestry, urbanization, and natural disasters. An understanding of these links can provide guidance for management interventions and policy options that promote human health. An ecosystem approach to management must be adaptive because of irreducible uncertainty in ecosystem function.
\end{abstract}

Key words Ecosystem; Public Health; Health

Resumo A promoção da saúde humana deve estar embutida na busca maior pela saúde do ecossistema. As intervenções estarão prejudicadas se os determinantes ecossistêmicos da saúde não forem levados em conta. Em caso extremo, se os ecossistemas perderem a capacidade de se renovarem, a sociedade ficará privada de serviços essenciais à sustentação da vida. As características essenciais da saúde ecossistêmica são a capacidade de manter a integridade e a de atingir metas humanas razoáveis e sustentáveis. Uma abordagem ecossistêmica para a pesquisa e gestão deve ser transdisciplinar e assegurar a participação dos diferentes atores. Tais características fornecem um meio à ciência para lidar melhor com a complexidade dos ecossistemas, bem como aos políticos e gestores no sentido de definir e atingir metas societais razoáveis. A abordagem ecossistêmica é capaz de determinar elos entre a saúde humana e as atividades ou os eventos que perturbam o estado e a função ecossistêmicos. A compreensão desses elos pode orientar as intervenções e as opções políticas que promovem a saúde humana. Uma perspectiva ecossistêmica na gestão deve ser adaptável, devido à incerteza irredutível da função ecossistêmica.

Palavras-chave Ecossistema; Saúde Pública; Saúde 


\section{Introduction}

In the course of history the human social system has become so influential and so entangled in the natural or ecological system that society can no longer act without more regard for nature. Human social systems have both local and global impacts that can impair the quality of life, predispose to disease, and even threaten life support systems. It has become essential to try to understand our world as a complex socio-ecological ecosystem and take such steps as are necessary to manage human affairs in ways that promote the health not only of people but also of the planet. Reductionist science by itself cannot deal with the complexity of this task. The ecosystem approach is one means to this end since it recognizes the interconnectedness of biotic and abiotic elements of the environment and effectively derives from a management perspective. Simply stated, managing for human health must be embedded in the wider pursuit of ecosystem health.

\section{The operative meaning of health}

Health is a logical and indeed universal goal for the ecosystem approach to managing human affairs. The wider application of the idea of health to ecosystems is consistent with contemporary views of what constitutes human health as articulated by the World Health Organization (WHO); health is not only the absence of disease but also the extent to which an individual or group is able, on the one hand, to realize aspirations and satisfy needs, and on the other, to change or cope with the environment. It is instructive to note that the notion of capacity is at the core of understanding health in this definition. An attractively simple definition of human health is the capacity for living.

Health embodies the two critical elements which are at play and need to be balanced in the present environmental crisis. Specifically they are preserving the ecosystem's capacity for self-reorganization and renewal on the one hand and achieving reasonable human goals on the other. While informed by science, health is not a science per se, as distinguished from medicine. Health is normative in character because it deals with human goals. As such it can adapt to changing circumstances.

The capacity for self-organization and renewal in the context of ecosystems has been termed "integrity". To some this term describes ecosystem function in the pristine state. Given that such conditions are extraordinarily rare or absent from our present world, in practice it is an ideal or benchmark against which to judge the effect of human activity or natural disturbance. Karr (1996) has defined "biological integrity" as the biological context and condition that is the product of evolutionary and biogeographic processes at a place where human influence is minimal.

Some believe that ecological integrity incorporates health as a feature. In this context the notion of health seems to denote largely freedom from degradation (disease), a limited view of health that is passé. Therefore it seems preferable to subsume integrity within the concept of health rather than vice versa.

The term integrity can also be used to describe the ability of social and economic structures to maintain their organization

Some scientists, policy-makers, and natural resource managers are finding the concept of ecosystem health a useful overarching goal for ecosystem management. They recognize that the pursuit of health accommodates the need for the integration of natural and social sciences with human values and extends in its application from individuals and populations to multiple populations of species, namely ecosystems. Health is also useful in that it is widely understood among the public. Health speaks to citizens.

\section{The ecosystem approach}

Ecosystems can be conceptualized as a nested spatial hierarchy (holarchy) of geographic units (holons) all embedded within the biosphere. Ecosystems have structure and function. Each level of the ecosystem hierarchy displays emergent properties. Their geography is sufficiently homogeneous to be ecologically consistent, e.g., a watershed. Ecosystem function reflects the complex interactions of physical and biological components that maintain ecosystem organization. Because of their complexity, which is unknowable in the final analysis, ecosystems are models or abstractions of reality chosen or defined to serve human purposes.

Ecosystems evolve over time, albeit they may have several relatively stable preferred states. They are to a degree unpredictable and can undergo catastrophic change under appropriate conditions. The system may be transformed into one with new characteristic features (attractors). Because of this unpredictability, ecosystem health management has to be adaptive (Kay, 1999; Murray et al., 1999). 
Nonetheless the determinants of ecosystem health are amenable to scientific study and management for preferred outcomes, a desirable process.

Ecosystem-based health management recognizes and takes account of the connectivity among different components within and among ecosystems. In some cases the connections are important to ecosystem function and stability (e.g., keystone species). In many cases the connections are much less determinative and hence of less importance to management decisions.

Because ecosystems have structure, they can be mapped, so it is not surprising that the Geographic Information Systems (GIS) technology is important in environmental management. Maps have extraordinary power to screen out unnecessary information and help untangle messy reality and facilitate a focus on an ecosystem's key features.

Modeling ecosystem function is more difficult, but information and computing technology has provided powerful tools to tackle this task. The use of "frameworks" to simplify and identify key relationships within and between ecosystems is helpful in understanding ecosystem functional relationships in pursuing management goals (Figures 1 and 2). However, modeling ecosystem function would seem a particularly challenging task in the quest to identify those circumstances in the ecosystem which are the principal determinants of human and ecosystem health.

The "pressure-state-response" framework is another means to focus research, analysis, and management on ecosystem problems (Pieri et. al., 1995). In this methodology a "stressor" is selected as an entry point (e.g., landscape disturbance). The "state" of the environment or ecosystem derives from assessment, and the "response" describes human actions or reactions. Specific infectious tropical diseases can be chosen as the "state" of particular interest.

\section{Key requisites in the ecosystem approach to health management}

The ecosystem approach to health management has two key requisites; transdisciplinarity and participation of stakeholders (IDRC, 1997).

\section{Transdisciplinarity}

Ecosystem approach to research and management must grapple with complexity that is not amenable to conventional reductionist science whether it be monodisciplinal, multidisciplinal, or interdisciplinal in nature. These approaches have failed to provide the means to effectively deal with a variety of crucial problems that impair the health and well-being of people, such as poverty, food security, environmental degradation, population growth, and some of the emerging and re-emerging diseases. These are complex problems where the integration of the multiple perspectives of many disciplines is required to create a new synthesis of understanding. Transdisciplinarity has emerged as a new means to this end.

Transdisciplinarity transcends conventional single and multidisciplinal approaches but does not replace them. It is a means to bridge the functional gap between the natural sciences and the social sciences/humanities, a gap which is the subject of much current discussion in the academic world (Wilson, 1998; Gould, 2000). Transdisciplinarity adds further methodology to the practice and implementation of science in addressing society's problems.

Peden (1999:3) describes transdisciplinarity as "transformation, going beyond disciplinary mind-sets into a re-conceptualization of phenomena, problems, goals, and approaches. It accepts complexity and pays attention to dynamic interactions (in space and time) between natural and human-made systems. Participation of end-users is essential, as is gender analysis. Accountability to end-users becomes intrinsic to the process. It enhances the possibilities for sustainable development".

It is unfortunate that in many academic environments the reward system discourages or penalizes academics who engage in activities outside their own narrow discipline.

\section{Participation}

Health is everybody's business, whether ecosystem or human, because it is fundamentally about meeting the reasonable goals of the stakeholders (satisfying needs). Scientists and decision-makers need to be enlightened by the aspirations, needs, and knowledge of the stakeholders. The involvement of stakeholders in research at the grassroots or community level has been facilitated by processes like participatory action research (PAR) and rapid rural appraisal (RRA).

The human or socioeconomic dimensions of ecosystems predicate participation with the stakeholders in ecosystem health research and management. This is so because: (1) stakeholders have important ecosystem knowledge of value to scientists and policy-makers; (2) there 
A conceptual framework, in this case an agroecosystem, illustrating a typical ecosystem hierarchy, its biophysical, social, and economic dimensions, and the essential parameters of health, namely, integrity and sustainable goal achievement.

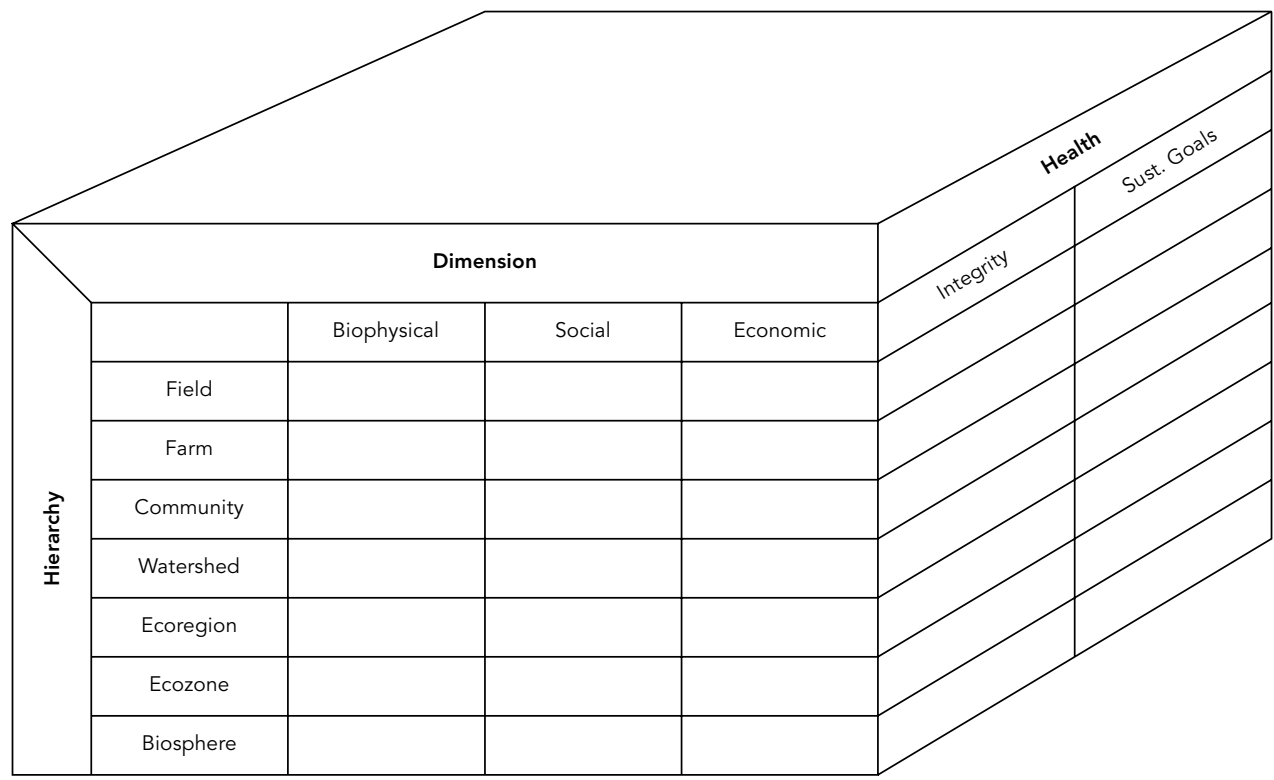

* Observe that the temporal dimension can be imagined by replicating the diagram in time.

Such a framework serves to simplify the complex relationships that must be considered

in ecosystem health management (VanLeeuwen et al., 1998).

is inherent uncertainty, i.e., unpredictability, in ecosystem research and management outcomes; (3) scientists have conflicting views; and (4) the stakes are high in environmental decision-making.

Participation can be a very difficult process! Some reasons are: conflicting priorities and/or cultures within or between communities; undesirable impacts occurring at other levels in contiguous or other levels of the ecosystem hierarchy; inadequate social structures to facilitate consultation with stakeholders; governance structures incongruent with geographical ecosystems (e.g., a watershed); and possible difficulty with legal and political legitimacy. In ecosystem management there are winners and losers, and success may depend on reasonable compensation for the losers. Participation would also appear to drive development projects towards general community development which may not be congruent with the objectives of specifically funded projects. Bureaucratic barriers between agencies are another obstacle to the kind of integrated action that is necessary in managing for ecosystem health. Given these obstacles, it is not surprising that IDRC (International Development Research Center) scientists believe that "ecosystem health proponents have identified community participation as a requirement to the approach, but have yet to identify explicitly the theories and methods they will use to achieve this goal" (IDRC, 1997:36).

Research and management for ecosystem and human health is basically about helping communities achieve reasonable and sustainable goals. The long-term success of managing for the health of ecosystems and improving human health ultimately depends on "empowering communities enlightened by knowledge" (Forget, 1999:47).

\section{Social capital and overcoming poverty}

Participation helps build social capital, an essential ingredient in overcoming poverty and enhancing development (World Bank, 1999). While agencies like the World Bank are still struggling to determine ways of measuring so- 
cial capital, some attempts at its definition have been made. It has been defined as "the norms and societal relations embedded in the social structure of society that enable tenable people to coordinate action to achieve goals". Institutional structures that build social capital tend to be horizontal rather than vertical and are in keeping with the kind of community involvement associated with the ecosystem approach to health management. The building of trust among the players is another important ingredient in this process. A civic community is not only the precursor and guarantor of good governance but also the key to sustained socioeconomic development (Serageldin, 1996) and the achievement of health goals.

\section{Ecosystem links to human health}

In the period when IDRC was laying the intellectual groundwork for its Ecosystem Approaches to Human Health Program Initiative, de Sauvigny (1995:21) postulated "the hypothesis underpinning the ecosystem approach to human health is that improved appreciation of the linkages between human activity, ecosystem conditions (e.g., natural or anthropogenic ecological degradation), human health, and public policy will provide a better understanding of the working of a system and the points of most effective intervention, be they health or other interventions". The IDRC Program is a test of this hypothesis.

Disease and health have been considered classically as dependent on the interaction of host, etiologic agent, and the environment. This classic triad does not go far enough. All three elements in any particular situation are linked to the biological, physical, social, and economic dimensions of the ecosystem hierarchy in which they are embedded (Figure 2). Human health interventions may be compromised if ecosystem-linked health determinants are not understood and managed.

There are many links between human health and ecosystem state and function which can serve to focus research and management. Biophysical links may occur in the immediate environment, e.g., mosquito vector breeding habitats or sources of harmful pollution, or to events in the remote biosphere, e.g., ozone depletion leading to local effects from harmful UV radiation. Socioeconomic links can vary from things like personal income, sexual behavior, and crime at the local level to factors like trade policies and the economics of pharmaceutical production at the global level.
Figure 2

An "onion skin" illustration of a conceptual ecosystem nested hierarchy which provides a framework for applying an ecosystems approach to a problem.

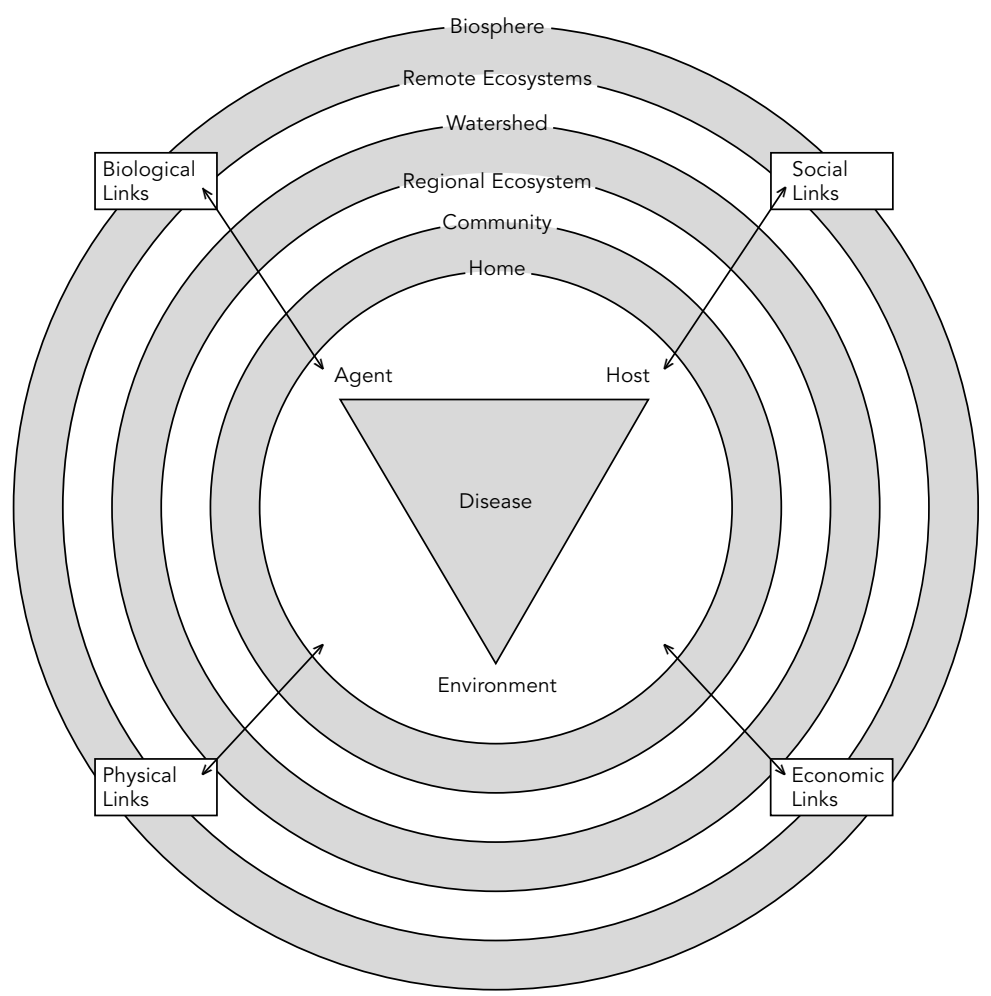

* In this example the framework guides the analysis of ecosystem relationships and links to the classic triad of host, agent, and environment, which is the point of departure in understanding disease causation and control. Environmental stressors such as mining and agriculture can also be analyzed in this framework, in which case the activity in question, rather than the disease, is illustrated in the core of the diagram (modified from Mergler, 1999).

Ecosystem links to human health can be approached in many ways. IDRC has focused its research program on the links associated with landscape disturbance in agriculture, mining, and urbanization. General examples of other links are any impairment to ecosystem function that affects water or air quality; and activities that impact vector-borne disease. Poverty is another major and often confounding factor in many ecosystem approaches to human health.

When landscape disturbances cause ecosystems to lose their integrity, i.e., the capacity for renewal, society loses numerous "nature's services" that are essential for human welfare, or in the extreme, human existence. While the value of natural products like food and lumber has been incorporated into our economy, most 
ecosystem services have not. Recently the value of these services worldwide was estimated at 33 trillion dollars, or nearly twice the world's annual GDP (Costanza et al., 1997). Some of the most important services are regulation of atmospheric composition, climate, and hydrological flows. Others are biological control of populations, nutrient cycling, soil formation, and erosion control and sediment retention, waste treatment, purification of water, and a diverse gene pool for medicine and agriculture. These services can no longer be taken for granted, and the development of public policies and resource economics must take them into account. If custodians of land the world over are to forfeit economic advantage to conserve ecosystem services for our global society, as they inevitably must, it will be essential to provide equitable compensation.

\section{The ecosystem health management process}

Strictly speaking it is impossible to manage ecosystems in the full sense of the word because of their unknowable complexity and frequent unpredictability. However, in practice, management can attempt to direct human activity for preferred ecosystem states, although it must be adaptive in order to adjust to unexpected change and new knowledge. The scientist's role in this management process is to inform the stakeholders about possibilities and options in an ongoing dialogue (Kay, 1999; Murray et al., 1999) that can respond to change and new circumstances, be they biophysical or socioeconomic. This base of information provides for resilience or adaptability.

The principal features of an adaptive management process for healthful management of ecosystems are: ecosystem assessment; ongoing participation of stakeholders; identification of indicators; development of a management plan; and implementation, monitoring, and adjustment (Gaudet et al., 1997; VanLeeuwen et al., 1998; Murray et al., 1999).

\section{Assessment}

Scientific assessment of the ecosystem in question involves defining, describing, and evaluating the ecosystem (both ecologically and socioeconomically), preparing the conceptual model and establishing a data base. Scientists operate in a trandisciplinary mode and consult in a meaningful way with the community. Description focuses on defining relationships that connect the ecosystem with higher level systems in which it is nested and lower order systems or communities of which it is comprised.

\section{Participation of stakeholders}

The assessment exercise is performed in the context of the stakeholder goals that are to be pursued. It must select those factors that are most germane to the goals of the enterprise and incorporate perspectives from different disciplines. It must integrate links in a socioecological framework.

These goals must be reasonable if they are to be sustainable in the long term. Stakeholders need to be adequately informed by scientists and have trust in both scientists and the social structure in which they operate (live). Issues need to be resolved.

\section{Selection or development of indicators}

Once goals and operating objectives are established, appropriate indicators need to be selected or developed and methods for their measurement established. Management must be guided by the appropriate indicators in order to achieve goals. Two old aphorisms are worth keeping in mind: "you can't manage if you can't measure" and "when you measure performance, performance improves". The selection and development of indicators is one of the important research domains. Different performance indicators may need to be tailored to the specific needs of stakeholders, policy-makers, and scientists.

\section{Preparation of the health management plan}

A management plan will address areas like policy interventions, indicator development, measurement, assignment of responsibilities, accountability, governance, and communication strategies.

\section{Implementation, monitoring, and adjusting}

Finally, implementation of the management plan involves monitoring priorities in relation to objectives and continuing the interaction between management, governance, agencies, and stakeholders, so as to facilitate adjustment to evolving circumstances. Management will include an ongoing research component. 


\section{Adapting education to the ecosystem approach}

Unfortunately, our universities and science in general have been largely reductionist in their approaches to pedagogy thus far. University graduates, including those in the health sciences, are inadequately prepared to wrestle with the inherent complexity of environmental and ecosystem health issues and problems. The pedagogy involved in teaching system's thinking is not served by current reductionist approaches of the traditional disciplines. Perhaps the only feasible approach to transdisciplinary education is to adopt a much more problem- or case-oriented curriculum in which students grapple with real ecosystem health problems, an approach familiar to many medical educators. Students must learn how to wrestle with complexity and integrate the rele- vant disciplines of the sciences and humanities that are involved in coming up with solutions or coping strategies. It would also be useful if students learned to interact with those from other disciplines that will have a stake in managing for ecosystem health, for example with students planning careers in public health. One can anticipate that courses with a more conventional format could provide training in useful techniques such as GIS and modeling and essential disciplinal knowledge such as ecology.

\section{Conclusion}

The ecosystem approach is a highly desirable, if not essential, context in which to promote human health at a time when environmental degradation has become inextricably linked to the long-term well-being of humankind.

\section{References}

COSTANZA, R.; D'ARGE, R.; DE GROOT, R.; FARBER, S.; GRASSO, M.; HANNON, B.; LIMBURG, K.; NAEEM, S.; O'NEILL, R. V.; PARUELO, J.; RASKIN, R. G.; SUTTON, P. \& VAN DEN BELT, M., 1997. The value of the world's ecosystem services and natural capital. Nature, 387:253-260.

DE SAUVIGNY, D., 1995. Approaches to international health: The health interventions approach. In: Health in Development/Development in Health: University-Based Strategies for Integrating Health Interventions with Community Development (D. Waltner-Toews, ed.), pp. 10-22, Ottawa: Canadian University Consortium for Health in Development.

FORGET, G. \& SANCHEZ-BAIN, W. A., 1999. Managing the ecosystem to improve human health: Integrated approaches to safe drinking water. International Journal of Occupational and Environmental Health, 5:38-50.

GAUDET, C. L.; WONG, M. P.; BRADY, A. \& KENT, R., 1998. The transition from environmental quality to ecosystem health. Ecosystem Health, 3:3-10.

GOULD, S. J., 2000. Deconstructing the "science wars" by reconstructing an old mold. Science, 287:253261.

IDRC (International Development Research Center), 1997. Ecosystem Approaches to Human Health Program Initiative. Program Prospectus 1997-2000. Ottawa: IDRC.

KARR, J. R., 1996. Ecological integrity and ecological health are not the same. In: Engineering Within Ecological Constraints (P. Schultz, ed.), pp. 97-109, Washington, D.C.: National Academy Press.

KAY, J. J., 1999. About the Ecosystem Approach. October 19 <http://www.res.waterloo.ca/u/jjkay/pubs/ ccsys/summation.html $>$.
MERGLER, D. Integrating human health into an ecosystem approach: A model for studying the impact of mining activities. In: International Congress on Ecosystem Health, Abstracts. Sacramento: International Congress on Ecosystem Health. (in press)

MURRAY, T. P.; KAY, J. J.; WALTNER-TOEWS, D. \& RAEZ-LUNA, E., 1999. An Adaptive Methodology for Ecosystem Sustainability and Health. October 29 <http://www.ovenet.uoguelph.ca/popmed/ ecosys/amesh3.html $>$.

NIELSEN, N. O., 1999. The meaning of health. Ecosystem Health, 5:65-66.

PEDEN, D. G., 1999. Mono-, multi-, inter-, and transdisciplinarity in IDRC research activities. Ottawa: International Development Research Center.

PIERI, C.; DUMANSKI, J.; HAMBLIN, A. \& YOUNG, A., 1995. Land Quality Indicators. World Bank Discussion Papers No. 315. Washington, D.C.: World Bank.

SERAGELDIN, I., 1996. Sustainability as opportunity and the problem of social capital. Brown Journal of World Affairs, 3:187-203.

VAN LEEUWEN, J. A.; NIELSEN, N. O. \& WALTNERTOEWS, D., 1998. Ecosystem health: An essential field for veterinary medicine. Journal of the American Veterinary Medical Association, 212:53-57.

WILSON, E. O., 1998. Consilience. The Unity of Knowledge. New York: Vintage Books.

WORLD BANK, 1999. Social Capital and the World Bank, Poverty Net, Social Capital for Development. October $1<$ http://www.worldbank.org/ poverty/scapital/bank1.html>. 